\title{
The investigation of the relationship between imagination from brand's suitability and brand preference Active brand detergent consumers in Sanandaj City
}

\author{
Sataie Moghadam, Ladan, Kamran Kasraie, Mansour \\ Department of Business Management, Islamic Azad University, \\ Sanandaj Branch, Sanandaj, Iran \\ E-mail address: kamranne@yahoo.com
}

\begin{abstract}
Keywords: brand preference; brand; imagination from brand's suitability; imagination from symbolic brand suitability; acquaintance with brand
\end{abstract}

\begin{abstract}
The current study want to determine the relationship between imagination of factional brand suitability and symbolic and trade name preference by Active brand detergent consumers. The population was consisted of all citizenship above 18 years old who live in Sanandaj city (423458 person). According to the study subject nature and studied population, it is used available sampling and 384 person completed the questionnaire based on the kokoran Formula. The study was done in a descriptive method of correlation type. Questionnaire was the information compilation tool that was distributed among respondents after estimating validity and perpetuity. Cronbach's Alph amount in questionnaire was 0/966 .Data were entered by spss20 software and data were analyzed by statistical Tests (spearman correlation coefficient). hypothesizes test results indicated that imagination variables of functional suitability and symbolic have relationship with Active brand preference by consumers. Consumers acquaintance with Active brand have positive relationship with functional and symbolic suitability imagination.
\end{abstract}

\section{INTRODUCTION}

We live in the area which other production attitudes, purchase and product. Cannot ensure the company survival in the market. Customers and rivals become intelligent and all of the companies which want to maintain their survival in this environment, should accept the marketing attitude and social marketing(Hosseini\& Rezaie,2011). Over the recent decades, researchers and market actives pay attention to "brand" issue. The reviews of previous readings show that with international trade growth, consumers of different countries expose various goods. This issue increases the consumer behavior researchers interest to examine the consumer's attitudes in a country or area in special goods.

This positive or negative attitudes may result from many factors such as price or quality of products. More efforts are done how the consumers values affect on their purchase behavior. This shows issue importance in world area(Haghighi\& Hossein Zadeh, 2009). In recent years, international trade increment and international companies attendance have lead to the wider emergence of various companies products among world markets(Khan\& Bamber,2008). Higher life standards, more power to buy, communication development all over the world and markets globalization help the fact that people know a lot about other countries and product and manufactures as a result, consumers are obtaining awareness about products and service and existing brands all over the world (Astous\& Boujbel, 2007). The result of previous studies show that consumers made a series of features and subjective images related to the brands in functional and symbolic dimension in the mind. This image are compared with trade name against various reference areas so that consumers think them ideal( Wong, Polonsky, Garma\& Romana,2008). Miller and Mills (2012) believed that whatever motivates the customer's enthusiasm to select a brand and inclination to buy, is that they accepted it's value. From the consumer's view, product position evaluation has special role in their inclination to brand's preference Li et al (2012) Recognized a mixture of consumer's values as an inclination persuasive to brand. They referred to 
the relative importance loyalty to brand and main function factor. This study fills the exiting scientific vacuum in relation to consumer behavior realization and effective views on future consumer's behavior(Pelton, Min, Youn, Knight \& Judith,2008). More studies are done about customers information process style and purchase patterns in developed countries but this issue doesn't enjoy rich fund and history in Iran. According to the mentioned subjects, the relationship recognition between imagination of functional and symbolic suitability on trade name preference was the main study aim study aim in Sanandaj city by Active brand detergent consumers.

\section{THEORETICAL BASIS}

Brand's suitability imagination definition: imagination from brand's suitability is an imagination from a trade name that is defined as a consumers perceptions of the brand. This perceptions and the image influence brand's image. A good image of a brand makes a good position of a brand in market. Scaling brand image is the position that a brand image is consistent whit consumer's expectations. Based on the scaling theory, consumer preferences are directly affected brand preferences. (jing bu\& et al, 2012). image of brand suitability are defined by the understood difference between actual brand's image and the expected image of consumer from the brand. In park et al (1986) opinion, brand image has two functional and symbolic dimension. Two brand image make two kind of brand suitability image( Li, Robson \& Coates, 2013).

\subsection{Brand suitability image dimensions:}

The views that separate lux brands from other market's brand, are priority customer service quality and high function. Functional value is about brands that estimates predetermined functional levels and it has positive effect on consumer views and it increases the price. Such that consumers have inclination to pay more money to satisfy their requirement( Li, Robson \& Coates, 2013).

\subsection{Ssymbolic suitability:}

High positive display standard of living and increasing opportunities for coordination with the selected social conditions are representative of brand symbolic value features. Based on this view, lux goods consumers use this goods as a elite and integrity symbols. Vignernon and Johnson (1999) referred to the lux brands as symbol and wealth sign and consumers position the relationship between(Li \& Coates, 2013).

\subsection{Symbolic and functional suitability:}

From access ability- diagnostic view, symbolic information are more available and they process and examine earlier than functional information degree access ability is a part or component which can retrieve an information from a memory to judge goods.

And diagnosis means the related information retrieved level.

Symbolic image relates to tangible features such as charm, friend ship and so on and it is briefer than functional image. As a result, symbolic information are a more available than functional information because they retrieve soon and information which retrieve soon, they are judged( Choo\& et al,2012).

\section{THE REVIEW ON ACCOMPLISHED STUDIES AND THEORETICAL FRAMEWORK FORMULATION}

Jing ha et al (2012) study result show that image of functional suitability, image of symbolic suitability have positive effect brand preference by chineese consumers. Li et al (2012) concluded that fashion life style, social/ affective values, understood utilitarian values and economic values affect chineese consu inclination to buy. And use goods with lux brand. Sirgy and SU (2000) concluded that image of destination suitability has positive impact on travel destination preference and trip preference to that place. Mollo and Mrills (2005) study results showed that whatever causes the consumer inclination to select a brand, is the functional and symbolic: value consumer acceptance. 
Consumer view about brand function and brand prestige have special role in their inclination to brand preference. Now according to the summary of theories and studies findings, the research hypothesizes are mentioned below:

\section{METHODOLOGY}

Descriptive research method is a correlation type and statistical population include all citizenship above 18 years old who live in Sanandaj city and they are 423458 persons. According to the research subject nature and statistical society, it is used available sampling method and 384 person completed questionnaire based on the Kokran. The study is done by a descriptive method. Questionnaire was the information compilation tool which was distributed after the estimation and perpetuity: by among respondents. To measure the brand preference, it is used the applied questionnaire in Li et al (2013) and Jing hu et al (2012) articles and it is used the questionnaires of the $\mathrm{Li}$ et al (2013) and Jing hu et al (2012) articles to measure the image the image of brand suitability. Cronbach's Apha was optained 0/996 in questionnaires. To analyze the data, it is used descriptive analytical analysis methods and inferential statistic analysis methods (spearman correlation coefficient). Statistical tests are done by SPSS software in this study.

\section{FINDINGS}

\subsection{Hypothesises test}

Main hypothesis

There is a positive relationship between functional and symbolic suitability with brand preference by Active brand detergent consumers. It is used spearman test to examine the hypothesis. As you see in the table, accounted significance level $(\operatorname{sig}=0 / 000)$ is below the study Alpha $(\alpha=$ $0 / 05$ )which show the significance of the relationship between two variables. The correlation type between two variables is $0 / 906$ which is very strong. Therefore, the $\mathrm{H}_{0}$ hypothesis is rejected and $\mathrm{H}_{1}$ hypothesis accepted. According to the results, we can say that symbolic and functional suitability image have positive relationship with brand preference by Active brand detergent consumers.

Table 1.

Spearman correlation coefficient of the relation between symbolic and function suitability image and brand preference by consumers

\begin{tabular}{|c|c|l|}
\hline $\begin{array}{c}\text { Dependent Variable brand } \\
\text { preference }\end{array}$ & independent variable \\
\hline $0 / 906$ & correlation & $\begin{array}{c}\text { coefficient } \\
0 / 000\end{array}$ \\
384 & $\begin{array}{c}\text { symbolic and functional } \\
\text { suitability image } \\
\text { sumber spearman } \\
\text { number }\end{array}$ & \\
\hline
\end{tabular}

\section{Secondary hypothesizes:}

there is a positive relationship between functional and symbolic suitability whit brand preference by Active brand detergent consumers. It is used spearman test to examine hypothesise. As you see in the table, accounted significance level $(\mathrm{sig}=0 / 000)$ is below than study Alpha $(\alpha=0 / 05)$ which is representative of the significance relationship between two variable. The correlation type is direct and positive and the correlation coefficient between two variable is $0 / 852$ which is very strong. So the $\mathrm{H}_{0}$ hypothesis is rejected and $\mathrm{H}_{1}$ hypothesis is accepted. According to the results, we can say that there is a positive relationship between functional and symbolic suitability image with brand preference by Active brand detergent consumers. A lo the accounted significance level $(\operatorname{sig}=0 / 000)$ is below than study Alpha $(\alpha=0 / 05)$ which is indicative of the significance relationship between two variables. The correlation type is direct and positive and correlation coefficient is $0 / 881$ between this two variables. Which is very strong so the $\mathrm{H}_{0}$ hypothesis is rejected and $\mathrm{H}_{1}$ hypothesis accepted. 
As a result, we can say that there is a positive relationship between symbolic suitability image with brand preference by Active brand detergent consumers.

Table 2: The correlation tests of the relationship between functional symbolic image variables and brand preference

\begin{tabular}{|l|l|c|}
\hline $\begin{array}{l}\text { Dependent variable Brand } \\
\text { preference }\end{array}$ & independent variable \\
\hline $0 / 852$ & $\begin{array}{l}\text { correlation } \\
\text { coefficient }\end{array}$ & functional suitability image \\
\hline $0 / 000$ & correlation coefficient & symbolic suitability image \\
$0 / 000$ & & \\
\hline
\end{tabular}

\section{CONCLUSION}

Based in the obtained result of this study, there is a positive relationship between functional and symbolic suitability image with brand preference by Active brand detergent consumers. The finding of this study are consistent with $\mathrm{Li}$ et al (2012) and Jing $\mathrm{Hu}$ et al results and they confirm this result based on the results of this hypothesis, when consumers put positive features for a brand, functional and suitability image will be increased. Good and service which have unique features, they make fortified emotional association with customers and finally they cause inclination to consume.

Jing $\mathrm{Hu}$ et al (2012) showed that there is a positive relationship between functional and symbolic suitability image with brand preference by a brand's consumers. Based on the obtained result, there is a positive relationship between functional suitability brand with brand preference by Active brand detergent consumers. The findings of this study are consistent with the Jing Hu et al (2012), Li et al (2012), Li et al (2013) and Ibrahimi et al (1391) studies and they confirmed this studies. Functional suitability image is about brands that estimate predetermined level and special belief about brand quality has positive effect on consumer's view and it increases the buyer's inclination to higher amount so that consumers have inclination to satisfy this requirement. More expensive products have better quality sometimes, this implication has more effect on consumer's attitude. If a person has information about good product quality but encounter low price product, he leaves information and feels that product doesn't have necessary quality. Based on the obtained results of this study, Symbolic suitability image has positive relationship with brand preference by Active brand detergent consumers. The findings of this hypothesis are consistent with the Li et al (2013), Li al (2012) and Jing Hu et al (2012) studies and the results confirm them. It must say that opportunity to show positive living standard and coordination enhancement with selected social conditions are indicative of the image feature of the brand symbolic suitability. Based on this view, consumer uses some goods as on elite and integrity symbol. People use some reliable goods to show their position. This persons pay a lot of money to buy this products while this products have lover price but this person have inclination to purchase this products. In fact, if a product's price higher than natural standards, it's prestige value will be increased. Based on the results, it is suggested that factors such as the applied technology level in product manufacture, product necessity, goods durability, easy availability to product and the shortness of purchase process and manufactures diversity have special roles on buyers values. So, manufacture companies should pay attention to this items. Our society people select their patterns based on the requirement, social class, their social. The media advertisements aim must not direct the advertisement for trade good but they should include values related to the Iran society cultural identity. The advertisements which pay attention to humanity cultural and national values, should be encouraged. 


\section{Reference}

[1] Ibrahimi, Abolghasem and Roodani, Amin ., The mortality marketing role on nutrition Consumer purchase behavior, mortal journal on sciences and technology, 4 (1)(2009).

[2] Hosseini, Mirza Hassan, Rezaie, Mehdi ., The investigation of effective factor on brand loyalty in dairy products market. Commercial management view, 5(38)(2011).

[3] Haghighi, Mohammad, Hossein Zadeh, Mashallah., The comparison of inclination amount to internal goods consumption at Tehran with other world areas and the examination of it's effects on evaluation and products preference. Management studies in Iran.4(13)(2009).

[4] Choo, Ho Jung, et al., 'Luxury customer value', Journal of Fashion Marketing and Management, 16(1)(2012).

[5] 'Astous, A.; Boujbel, L., Positioning Countries on Personality Dimensions: Scale Developmentand Implications for Country Marketing, Journal of Business Research, 60(3)(2007).

[6] Khan, H.; Bamber, D., Country of Origin Effects, Brand Image, and Social Status in an Emerging Market. Human Factors and Ergonomics in Manufacturing, 18( 5)(2008).

[7] Jing $\mathrm{Hu}$ and Xin Liu \& Sijun Wang \& Zhilin Yang ., The role of brand image congruity in Chinese consumers' brand preference,Journal of Product \& Brand Management,21(1)(2012).

[8] Li, Ning, Robson, Andrew, and Coates, Nigel ., 'Chinese consumers' purchasing: impact of value and affect', Journal of Fashion Marketing and Management, 17(4)(2013).

[9] Li, Guoxin, Li, Guofeng, and Kambele, Zephaniah ., 'Luxury fashion brand consumers in China: Perceived value, fashion lifestyle, and willingness to pay', Journal of Business Research, 65 (10)(2012).

[10] Miller, K.W. and Mills, M.K., Probing brand luxury: a multiple lens approach, Journal of Brand Management, 20(1)(2012).

[11] Mowle, J. and Merrilees, B., A functional and symbolic perspective to branding Australian SME wineries, Journal of Product \& Brand Management, 14(4)(2005).

[12] Park, C.W., Jaworski, B.J. and MacInnis, D.J., Strategic brand concept-image management, Journal of Marketing, 50(1)(1986).

[13] Pelton,Lou, Min-Young Lee, Youn-Kyung Kim, Dee, Knight \& Judith Forney., Factors affecting Mexican college students' purchase intention toward a US apparel brand, Journal of Fashion Marketing and Management, 12(3)(2008).

[14] Sirgy, M.J. and Su, C., Destination image, selfcongruity, and travel behavior: toward an integrative model, Journal of Travel Research, 38(4)(2000).

[15] Wong, Y.; Polonsky, C.; Garma, J.; Romana, M., "The impact of consumer ethnocentrism and country of origin sub-components forhigh involvement products onyoung Chinese consumers'product assessments, Asia Pacific Journal of Marketing and Logistics,20(4)(2008). 